\title{
Viv Ellis
}

King's College London \& Høgskolen i Bergen

Email:viv.ellis@kcl.ac.uk

\section{The challenge of transformation: Å arbeide med kunnskapsproblemet i lærerutdanningen}

I read the articles in this special issue at a time of continuing turbulence in the policy environment in England, particularly for teacher education and particularly for university involvement in this activity. The March 2016 government white paper Educational Excellence Everywhere (DoE, 2016) not only promised to convert all schools in England to academies run by a large number of national 'chains' or trusts (thus severing the connection between local communities and their schools in a relation of democratic accountability), the white paper also proposed to abolish the national qualification for teachers Qualified Teacher Status (QTS). These changes came on top of the previous coalition government's reforms (DoE, 2010) that used various policy levers to disadvantage universities in the quasi-market for initial teacher education; to introduce a new, supposedly school-led route called School Direct (that would be awarded the majority of places for teacher education), to the detriment of universities' funding; and to create conditions that would privilege (through subsidy) philanthropic providers of training such as Teach First and open the way for more private providers to enter the market.

The consistent political aim in England, over many years now, has been to marginalize universities in the preparation of new teachers. If they could have been entirely eliminated and ejected from the market-place that would have been a better option for recent governments but, reluctantly and often with ill-temper, ministers have had to come to recognize that only the universities have the infrastructure that can produce the approximately thirty thousand new teachers England needs every year; only the universities benefit from such economies of scale. And, even more reluctantly, given these governments' commitments to the marketization of public services, consumers (the prospective student teachers) have continued to be swayed by the brand recognition and evident quality the universities have accumulated over many years and they continue to apply to the universities and pay their fees with student loans. Given a free choice and saddled with tuition fee debt, these consumers continue to choose proven, reliable, high-quality provision organized by universities no matter how sternly (and in nakedly ideological ways) ministers try to persuade them otherwise. This is no surprise: if the whole system is mainly funded by student 
debt, most students will not be seduced by an untested political whim, if they are given any kind of choice.

None of which is to deny that university departments of Education in England have been considerably damaged over the last six years. This damage is evident in a number of ways: the conversion of substantive academic posts to temporary, teaching-only ones and the re-designation of existing staff; the inability to plan adequately a department's future given that universities have only been able to calculate their funding on a year-to-year basis (with allocated student numbers for teacher education programmes always liable to be cut further); the decline in the number of academic staff entered for the Research Excellence Framework (REF) and therefore deemed research-active; an atmosphere in many departments in which teacher educators feel not just undervalued but under attack, their work publicly denigrated by politicians in the media and by neoconservative bloggers and users of Twitter. And, of course, the profession has been damaged too in some fairly obvious ways that are increasingly hard to deny: we now have critical shortages of teachers in some subjects and geographic areas and, consequently, there is an increasing number of 'hard-to-staff' schools; in England, we also have a problem retaining teachers in the profession over their first few years. Despite government denials, this crisis of teacher recruitment and retention was finally confirmed by the independent National Audit Office earlier this year (NAO, 2016).

For three years, until March this year, I managed this unfortunate collision of circumstances during my term as head of a department of Education at a research university (Brunel, in the west of London) completely committed to teacher education but simultaneously aware of the high risks involved. At the same time, in leading this department, it was my responsibility to create a shared vision among colleagues of what we would want to do with teacher education, how we might innovate and do so in ways that whilst not confined to reacting to the fairly malign policy environment nonetheless had to acknowledge it.

And then I would travel to Norway, where I have a professor II position at Høgskolen i Bergen, an institution that has also faced the ongoing reforms of successive Norwegian governments over the last ten years or more and is now preparing to implement the 2017 reform and a five-year Master's degree for all primary teachers (Kunnskapsdepartementet 2014). How different teacher education reform looks in Norway! To deliver the 2017 programmes, institutions like Bergen University College need to develop the competence of their academic staff, recruit more professors in order to meet formal demands for accreditation, support the needs of the growing number of master's students and build an academic infrastructure that will support the intellectual engagement of their students in pedagogical development at a high level. The hope is that this enhanced university education will have a positive impact on schools and on school students' attainment in years to come. At the same time, Norway has funded $\mathrm{PhD}$ studentships for teacher educators through national 
graduate schools (NAFOL and NATED) over several cohorts and institutions like Bergen University College have also been allowed to accredit their own $\mathrm{PhD}$ programmes. National research initiatives like PRAKUT, Education 2020 and FINNUT have been generously financed to support capacity-building in educational research, including teacher education institutions. So times are changing in Norway too and universities, university colleges and teacher educators are facing significant challenges. The nature of these challenges is very different to those we are experiencing in England but they are challenges all the same.

Yet as I read the papers in this special issue, I think the challenges we are both facing are very similar in one important respect: it seems to me that in England and Norway (and probably some other places too) we still haven't worked out the relationship between the teaching profession and the university in the activity of teacher education. We might have some ideas about schools as places for student teachers to learn (these ideas vary quite a lot but we do have them) but we haven't worked out the nature of - or the terms of - the relationship between one of the largest professions in our societies, a profession essential to our societies' success, and a discipline within higher education that is in a relation to the practice of the profession but is not it. In the next section of this paper, I want to explain what I mean with particular reference to the articles in the special issue.

Working out the relationship between the profession and the university: two aspects of a knowledge problem

In trying to work out the relationship between the profession and higher education institutions in the activity of teacher education, in Norway as in England, we seem to be confronted by two aspects of the same knowledge problem. The first aspect is the complex interaction between the forms of knowledge that work together to become professionally useful for teachers in classrooms with children and young people. Some forms of knowledge have harder edges, are apparently more codifiable and probably more exchangeable for academic credibility and advancement. These forms of knowledge might be described as apparently more 'scientific' and their modes of production are sometimes modeled on those assumed to be dominant in the natural and life sciences, engineering and medicine. These forms are thought to be purer, more reliable, more certain and able to be confidently articulated. They emerge within the specialized activities of higher education and research institutions; they have academic status. The other forms of knowledge are often more local and contextual, although not always. They are not always tacit; they may well be externalized within professional settings such as teacher conferences, teacher unions, subject associations and in textbooks and how-to guides and, as such, 
they have accumulated over time and have been deliberated within professional communities. In other words, this kind of knowledge is not necessarily composed only of what Vygotsky called 'spontaneous' or everyday concepts (Vygotsky, 1986); this knowledge has been deliberated within an intellectually interdependent community over time, it has been externalized within the professional culture of teaching but it uses a different lexicon and permits different meanings to the forms of scientific knowledge that is promoted, shared and valued within universities.

A sub-question connected to this aspect of the knowledge problem is the question of the relationship between the teacher's knowledge of the subject being taught (sometimes called their 'subject knowledge') and their knowledge of teaching or pedagogy. This question is particularly relevant to teachers in secondary schools, especially upper secondary schools, who often see themselves - and are seen - as practitioners in an academic discipline (Mathematics, History, Physics, etc.) as well as a school teacher. The question also arises for teaching in primary or elementary schools, however.

The second aspect of this knowledge problem is whether and where teachers develop these different forms of knowledge: how do teachers learn to become a professional? And how does the profession itself learn and develop? So, as with the first aspect of the problem, this is a collective issue rather than one concerned with the production of a succession of individual practitioners. Professionals, teachers, join a profession, something that is already alive and in motion just as are the specific practices teachers join in with in particular schools as work-places. For the profession of teaching, though, there are multiple sites of learning just as there are multiple settings of professional practice. But to live as a profession, the occupational group of schoolteachers must own and develop both a specialist body of knowledge they hold in common (across different settings) as well as the means and methods of accessing and adding to this knowledge-base. It would be very strange if the profession of teaching handed over these knowledge responsibilities to anyone else (such as university departments of Education) for then surely teaching would cease to be a profession? Trying to work through the challenges presented by this knowledge problem in both its aspects seems to me to be vital for teacher education in Norway just as it is in England. This means thinking through more clearly than perhaps we have until now what kind of relationships should exist between teaching as a profession and teacher education as an activity of higher education.

In their paper in this special issue, Hermansen and Mausethagen tackle the first aspect of this knowledge problem directly using the contrast between abstract, propositional knowledge and contextual and experientially-derived knowledge as an illustration of what is so often seen as a stand-off between theory and practice in teacher education. But it would be wrong to move forward on the basis of accepting this stand-off. As I have argued and as Hermansen and 
Mausethagen as well as Angelo acknowledge, we are talking about forms of knowledge not about a distinction between knowledge/not-knowledge. Relatedly, through a fascinating historical study of core teacher education curricula in Norway between 1837 and 2010, Vinje's paper traces the shift in authority and related forms of knowledge away from the teaching profession (in the 1837 curriculum, directly largely by headteachers) to the universities and, specifically, the dominance of the University of Oslo in deciding the content by 1965. Vinje writes, 'the university did not educate for a profession' and notes that by 1965 the concepts teaching and learning were absent from the curriculum (with the exception of one mention of the word 'teaching' in a discussion of developmental psychology) as it moved - and moved consciously rather than accidentally - away from the activities of the school classroom. Professional forms of knowledge had been effectively eliminated from the university's curriculum in favour of more obviously academic studies. With particular reference to teachers' subject knowledge, Flognfeldt's paper argues that pedagogical development is key and the use of pedagogical development projects becomes more important than any measure of or proxy for subject knowledge per se, something that is borne out by the research literature in the field (c.f. Ellis, 2007). Mathé, Føinum, as well as Lund and Eriksen also pick up on this important relationship in their papers.

With reference to the second aspect of the knowledge problem and how student teachers learn to become professional, Fosse's paper notes the traditional reliance on student teachers to do some fairly challenging boundary-crossing (between the university and school classrooms) and to undertake some complex and demanding 'translation work' too - translating 'campus-based activities' into 'school-based activities' (the professional practice of teaching). Overcoming this structural fragmentation is seen as a priority in several of the papers, including Klette and Hammerness's and Brevik and Gunnulfsen's papers on the meaning of coherence in teacher education design. Klette and Hammerness suggest that structural integration in design-terms is necessary in order to build the coherence required for the students to make sense of their experience in the teacher education programme. However, the authors also note that an over-emphasis on coherence can limit the possibilities for powerful learning to occur. Coherence at a structural and rhetorical level does not necessarily create conditions conducive to innovation, for example; innovation, including in the public services, tends to arise from situations within which there is more variation (Miettinen, 2013). Jakhelln and colleagues' paper, arising from a pilot of the 2017 Norwegian curriculum reform, suggests how the Master's thesis might take on particular significance as a boundary object that enables dialogue between professional and academic settings. Another set of papers, including those by Klemp and Nilssen, Brox, and Røkenes, indicate the potential of new technologies and teachers' own digital competence to disrupt usual practice and open it out for discussion in developmental ways. 
Thorsen's paper on the school teacher's role (as 'practice teacher') in teacher education is interesting for the way in which it brings discussion of these two aspects of the knowledge problem together, with reference to some particularly lively data from an interview study. A teacher comments (about their relationship with the university teacher educator), 'we are on two different planets'. School visits by the teacher educator are appreciated socially but they are not necessarily seen as 'participatory' and the practice teacher's role seems passive and simply in receipt of guidance and 'pearls of wisdom' from academics during meetings at the university. At stake are the different forms of knowledge held by the actors in each setting (school and university), the value attached to each and the scope for give-and-take between them. Thorsen concludes by suggesting that the role of 'practice teacher' in the school may need to be developed and framed differently, more professionally, with clearer expectations. After reading the paper, I felt that the same might be said of the university teacher educator's role too.

Several papers in this special issue report on pilot or otherwise developmental projects that address this knowledge problem and set out new visions for the design of initial teacher education in Norway. Lund and Eriksen's, Vestøl's and Jakhelln and colleagues' papers, all associated with the national centre of excellence ProTed, do just that and draw on a range of systematic enquiries that have taken place over several years, enquiries that seek to explore the challenge of improving teacher education in Norway. The promise and potential pitfalls of the new Master's thesis, for example, are highlighted well in Jakhelln and colleagues' paper, arising from a pilot of the reform at the university in Tromsø. Also, Nesje highlights new partnership models in her paper about Teach First Norway as well as the power of the Teach For All rhetoric in motivating prospective teachers (see also Ellis et al., 2015). In my response to the articles in this special issue and in my other work, I have been trying to clarify the nature of the challenge faced by teacher education in England and in some other English-speaking countries. From my reading of these papers and in my own experience of working in Norway for the last five years, I am arguing we are grappling with the same challenge even though the direction of policy in each country is so very different. It is the nature of this challenge that I want to clarify in the final section of the paper.

Beyond transfer and translation: The challenge of transformation across complex boundaries

In Transforming Teacher Education (2015), Jane McNicholl and I reported on a range of studies that suggested that, in England, we really haven't worked out the relationship between the teaching profession and universities' involvement in initial teacher education. Our focus was on the work of the university-based 
teacher educator and our argument was that this class of academic worker has been proletarianised and this situation has been to the detriment of the university discipline of Education and also to the profession, as well as individual teacher educators who have seen their careers limited and, indeed, their employment made precarious. Although we focused specifically on England, we found some evidence of the same process in Scotland and the international research literature reveals this to be a common phenomenon in English-speaking countries' higher education systems (e.g. Dillabough \& Acker, 2002; Liston, 1995; Nuttall \& Brennan, 2015).

In our research, we took a broadly cultural-historical perspective to investigating the research questions whilst also drawing on related concepts from organizational theory, the sociology of science and studies of innovation. We also connected our arguments to recent sociological analyses of the professions (e.g. Adler et al., 2008) and changes to higher education and the public responsibilities of universities in democratic societies (e.g. Burawoy, 2011). In the concluding section of this paper, I want to use ideas from organizational theory, specifically the work of Paul R. Carlile (2002), to clarify the twin aspects of the knowledge problem that I see threaded through the papers in this special issue and that I have been arguing represent a shared challenge for both England and Norway in developing initial teacher education. I offer this summary by way of conclusion to the paper but also as a stimulus for further questions and exploration in our different contexts. Carlile's work on forms of knowledge and how knowledge is or isn't shared across boundaries of practices is useful and important for our interests in teacher education in that he takes an explicitly 'political approach' to the knowledge problem and acknowledges that 'different interests impede knowledge sharing' (Carlile, 2002, 555; my emphasis) and, consequently, innovation. Carlile's work is situated in commercial settings and is concerned with how profitable innovations might address novel problems in the car manufacturing process, for example. However, Carlile's work is also useful in relation to professional settings where complex problems ('novelties' in a process, in Carlile's terms) are inevitable and continually emergent and require that professionals both draw on specialist knowledge held in common by that profession but also, potentially, contribute to that specialist knowledge through particularly creative interventions.

Carlile identifies what he refers to as three 'progressively more complex boundaries' that diverse actors who collaborate on an activity have to negotiate. Borrowing from linguistics, he terms these syntactic, semantic and pragmatic, meaning that, at first, there needs to be the possibility for communication based on similar meaning-making units; second, there needs to be the possibility for shared meanings to develop; and thirdly, in order to solve the problem at-hand or to achieve the innovation, there needs to be the possibility for awareness of the whole context and not just the different perspectives of the actors to be 
brought to bear. Carlile also identifies in parallel three progressively more complex knowledge processes that are necessary for these boundaries to be negotiated, processes in which the domain-specific knowledge of each actor is at stake in the quest for common knowledge. He terms these transfer, translation and transformation and doesn't underestimate the conditions needed even for transfer, the least complex process to occur. Transfer requires some level of stability in structures and communication patterns. Translation across semantic boundaries then requires some degree of openness to sharing that will allow these potentially shared ideas to 'stick' in practices, albeit in some limited way (Carlile, 2002, 559). But transformation at a pragmatic boundary requires that the different actors have different interests and, centrally, that knowledge is 'at stake'.

According to Carlile, transformation - the creation of new ideas that engage with but extend older ones in surprising and successful ways - arises out of a mixture of the domain-specific knowledge of each actor that is seen to be useful and 'the knowledge that has been determined to be of consequence' in the particular situation (ibid.). The resulting 'common knowledge' is consequential in that it allows the activity to develop over a complex, pragmatic boundary. A common lexicon is necessary for transferring domain-specific knowledge across a boundary but also shared meanings that allow the problem to be identified in order for domain-specific knowledge to be translated into a new situation. But when trying to negotiate a pragmatic boundary with diverse actors (and here we might include policy makers as actors too), it is also necessary to establish common interests on the basis of different forms of domain-specific knowledge and then to create conditions that allow for trade-off and opportunities to transform and break away from domain-specific knowledge. And, as Carlile puts it, 'to create common interests to share and assess knowledge requires significant practical and political effort' (p. 560). To provide an activitytheoretical interpretation instead, different communities develop different ways of organizing and communicating their work but, for expansive learning to occur, new ways of organizing and communicating need to emerge that allow these communities to break away from former patterns of activity (Engeström, 1987). Transforming teacher education in ways that promote the expansive learning of the system requires some pretty heavy-going relational (for which read, political) work.

So what will teacher education look like in Norway in the years after 2017? Will we see the fruits of the challenging work of transformation at the complex pragmatic boundaries of the practices of (minimally) the teaching profession, university departments of Education and education policy-makers? What tradeoffs will have occurred for a new configuration of the activity to emerge? How will the universities acknowledge the domain-specific knowledge of the profession? What will the new forms of common knowledge look and sound like? Or will the business-as-usual of trying to translate domain-specific 
knowledge from the university into school classrooms continue, but this time encoded in a master's thesis? Will the reforms produce a generation of primary school teachers with greater research competence but who enter a profession that still hasn't worked out its relationship with the universities' role in teacher education?

\section{References}

Adler, P. S., Kwon, S.-W., \& Heckscher, C. (2008). Professional Work: The Emergence of Collaborative Community. Organization Science 19(2), 359 - 376.

Burawoy, M. (2011). Redefining the Public University: Global and National Contexts. In Holmwood, J. (Ed.), A Manifesto for the Public University (pp. 27 - 41). London \& New York: Bloomsbury Academic.

Carlile, P. R. (2002) Transferring, Translating and Transforming: An Integrative Framework for Managing Knowledge Across Boundaries. Organization Science 15(5), 555 - 568.

Department of Education (DoE) (2016). Educational Excellence Everywhere. London: Department of Education; available at https://www.gov.uk/government/publications/educational-excellence-everywhere.

Department of Education (DoE) (2010). The Importance of Teaching. The Schools White Paper. London: Department of Education. Available at https://www.gov.uk/government/publications/the-importance-of-teaching-the-schoolswhite-paper-2010.

Dillabough, J.-A. \& Acker, S. (2002). Globalisation, women's work and teacher education: A cross-national analysis, International Studies in Sociology of Education 12(3), 227-260.

Ellis, V. (2007). Subject Knowledge and Teacher Education: The Development of Beginning Teachers' Thinking. London \& New York: Continuum.

Ellis, V., Maguire, M., Trippestad, T., Liu, Y., Yang, X., \& Zeichner, K. (2016). Teaching other people's children, elsewhere, for a while: The rhetoric of a travelling educational reform. Journal of Education Policy 31(1), 60-80.

DOI:http://10.1080/02680939.2015.1066871.

Ellis, V. \& McNicholl, J. (2015). Transforming Teacher Education: Reconfiguring the Academic Work. London \& New York: Bloomsbury Academic.

Engeström, Y. (1987). Learning by expanding: An Activity -Theoretical approach to developmental research. Helsinki: Orienta-Konsultit.

Kunnskapsdepartementet. (2014). Lærerløftet. På lag med kunnskapsskolen, Strategi. Tilgjengelig. Available at https://www.regjeringen.no/globalassets/upload/kd/vedlegg/planer/kd_strategiskole_web. pdf.

Liston, D. P. (1995). Work in Teacher Education: A Current Assessment of U.S. Teacher Education. In Shimahara, N. \& Holowinsky, I. (Eds.), Teacher Education in Industrialised Nations. New York: Garland Publishing.

Miettinen, R. (2013). Innovation, Human Capabilities and Democracy: Towards an Enabling Welfare State. Oxford: Oxford University Press.

National Audit Office (NAO) (2016). Training New Teachers. London: National Audit Office. Available at https://www.nao.org.uk/report/training-new-teachers/.

Vygotsky, L. S. (1986) Thought and language. (A. Kozulin, Ed. \& Trans.). Cambridge, MA: MIT Press. 